CHAPTER 3

\title{
The Economy of Poetic Style
}

The café owner shouted in angry exasperation:

"Are you going to force your recitations on us? That's the end-the end! Didn't I warn you last week? . . ."

The old poet sweetened his tone a little as he tried to soothe the angry man and said:

“This is my café too. Haven't I been reciting here for the last twenty years?"

The café owner took his usual seat behind the till and replied:

"We know all the stories you tell by heart and we don't need to run through them again. People today don't want a poet. They keep asking me for a radio and there's one over there being installed now. So go away and leave us alone and may God provide for you"

Naguib Mahfouz, Midaq Alley

In Chapter 2 we examined a few of the many relationships which obtain between epic poets and the epic poem they perform. We now turn our focus to audiences and performance situations in order to examine the social economy of poetry and poetic style: Why do audiences patronize the poem (and by extension the poets)? How do they do so? How does the performance emerge from the poet's interaction with differing audiences and differing patronage structures? And finally, how do audiences, patronage, and performance situations affect the stylistic choices of the poet, the tone of the performance itself?

I use the term "social economy of poetic style" here as an image of my own understanding of the interaction of these disparate elementsthat is, an economy consisting of the on-going interaction of multiple forces that translate the material power of wealth (patronage) through markets (audiences) via products (epic poetry) that possess aesthetic characteristics (style) that are in great part determined by the financial and market pressures that help create them. Poetry, power, social alle- 
giances, and money are all part of the traditional performance process, though Western researchers of ten choose to divorce the "real" world of money and patronage from the "higher" realm of poetic form and artistic tradition. In this regard, that Western view of art and poetry which privileges certain forms of expression and distances them from their economic and sociopolitical dimensions is poorly adapted for the analysis of expressive culture in traditional societies. No epic singer in al-Bakātūsh would deny the direct influence of patronage and payment upon his performances; it is an accepted part of the profession. The difficulty in analyzing the interaction of money, power, and poetry lies primarily in the lack of a beginning or an end to the process; no a priori precedence exists for any one element over the others, for we are not examining a chain of causal relationships but rather an interacting whole. Any starting point must therefore be somewhat arbitrary, and though the relationships we highlight may be consistent, they cannot be exclusionary.

In this volume I focus on one specific performance context, the sahra, or private evening gathering, and on audiences drawn from a limited population (the inhabitants of al-Bakātūsh and their occasional guests). In order to achieve a fuller understanding of the role and characteristics of the sahra context, however, I map out the social implications of the context itself through comparison with other performance situations. Each of these contexts, I argue, represents a separate complex of interacting factors that influence both performer and listener. Expectations, behaviors, and evaluative frameworks all coalesce into definable and describable performance environments.

The problem of unraveling a complex set of interactions such as is presented to us in performances of traditional texts is not only one of identifying what actually takes place in a specific performance or even repeatedly within a specific performance context, but also in understanding what does not, that is, in understanding how each performance or context differs from other performances in other contexts. Performances and performance situations resonate with and against each other, and what is, by comparison, absent in a particular performance may be as eloquent and as significant as what is present.

The performances we study as folklorists possess a quality that, for lack of a better term, we choose to call "traditional." The term comes to us loaded with ideological baggage, but part of its connotative meaning is highly significant here. These performances invoke performances of the past, performances of identifiable and nameable texts of the past, and therefore they create a constant chorus of voices, a multivocality dependent upon re-iteration. As a methodology, then, it would be folly for 
a folklorist to examine a single avatar of a traditional text if other examples were also available. The comparison of different renditions of the same material by the same poet, and by different poets, becomes essential for understanding the "absences," the mute voices, of the epic within a given performance.

This chapter therefore first treats, as distinctly as possible, a series of contexts for Sìrat Banì Hiläl performances. By understanding the normative forms of performances in different contexts, we can come to a rough understanding of when and why the norms are broken, that is, how such "presences" or "absences" communicate in performance.

Next, focusing specifically on the sahra, we turn to audiences in alBakātūsh and assess their attitudes toward, and participation in, the Sìrat Bani Hilal tradition in an attempt to flesh out as completely as possible the social background for the performance processes examined in the concluding part of this study. The differing tastes of various social groups within the village have engendered different acceptable performance styles; as a result, individual poets in al-Bakātūsh have established their own coteries of listeners. Four of these poets and their individual performance styles are introduced at the end of this chapter. These four were chosen as representative of the capacities and performance styles of the entire al-Bakātūsh epic-poet community. All of the texts in the remainder of this work are drawn from performances by these four artists so that the reader can acquire a sense of the interplay between the performers' personalities and their performance styles.

\section{Traditional Performance Contexts}

Before examining in some detail the contexts for professional performance of Sirat Bani Hilall, that is, performance by the epic singers, it is worth noting that the epic both exists and is transmitted in many nonprofessional contexts as well. Within the community of al-Bakātūsh there are adults who narrate portions of the epic as prose tales; these are of ten directed, at least superficially, to children. There are also a number of connoisseurs in the village, and even more in the surrounding hamlets, who can narrate extensively from the epic tales with varying amounts of intermittent poetry; these "reciters" narrate principally for informal gatherings of adult male companions. At least one older man in the region is capable of sustained poetic narration which he delivers in a high declamatory style, though he does not sing or use any musical 
accompaniment. Furthermore, at least two chapbooks, each representing only a fragment of the epic, have circulated in the village in recent years. ${ }^{1}$

In this one location and time period then, the epic of the Bani Hilāl is found in verse, cante-fable, and prose renditions, and in both written and oral forms; there is no evidence that this was ever not the case. We must assume that a researcher passing through this region doing primarily collection or survey work might well have encountered the epic in any of its various forms and then continued on unaware of its cognate performance forms. With this in mind, we must address with care not only the map of literary forms and performance modes which emerges from our sketchy data from most regions (see the Introduction), but also theories such as those advanced by Menéndez Pidal and others concerning the historical "breakdown" of epic into balladic and other simpler forms. ${ }^{2}$

Epic poets in the Nile Delta region have traditionally performed at nearly all local celebrations: at weddings, local saints' festivals, circumcisions, and at private evening gatherings (sahrät or layālì). They have also maintained itinerant circuits of cafés and patron families over a wide geographic area through contacts built up over generations. For poets who are not gifted enough to attract significant patronage, or for any poet when economic needs dictate, there are less respected forms of income: playing in town squares (usually praise songs to the Prophet Muhammad rather than epic) for whatever pennies are given by passersby, riding trains and singing for similar pittances, even sitting at the edges of fields to entertain villagers as they harvest or plant in return for a meal and some small payment. These latter activities are of ten viewed as "beggary" or "vagrancy" (tasawwul) by villagers. They are admitted to reluctanctly by the poets and referred to pejoratively by others. The poets, as might be expected, are pragmatic about this distinc-

I. I obtained and then xeroxed these two chapbooks. They were both incomplete, undated copies of the same edition of "Sirat banī hilāl fì qișșat abū zayd al-hilālī wa-l-nā'isa wa-zayd al-cajāj" from the Maktabat al-jumhūriyya al-carabiyya publisher in Cairo. Several poets and villagers stated that a number of chapbooks of Sìrat Bani Hilal had been present in the village years ago; many of these were said to have been destroyed by the dampness that accompanies the annual winter rains.

2. "Briefly stated, Menéndez Pidal's theory of 'fragmentation' posits that as the old epic fell upon hard times, juglares found that their audiences displayed an affinity for hearing certain favorite parts of the old cantares, usually brief narrative episodes or dramatic exchanges of dialogues that marked moments of high tension in the tradtional epic songs, and that these sections lifted from the longer poems came to be sung independently." Merle E. Simmons, "The Spanish Epic," in Oinas, Heroic Epic and Saga, 229.

The most useful of Pidal's many presentations of these ideas is found in Ramón Menéndez Pidal, Poesía juglaresca $y$ orígenes de las literaturas románicas, vol. 3 (1957), and idem, Romancero hispánico (1953). 
tion: invited appearances are fine when they are plentiful and generate sufficient income, otherwise, poets, like everyone else, must seek God's bounty wherever they can find it.

A number of the traditional contexts for the performance of epic poetry, however, are rapidly disappearing or undergoing radical transformation. Urban areas rejected the epic tradition some time ago as rural, "hick," and provincial. Though performances in Cairo were common until the late nineteenth century, in the twentieth century performances of Sìrat Banī Hilāl have been primarily a rural phenomenon. ${ }^{3}$ Now, even in the countryside, things are changing.

According to the poets of al-Bakātūsh, the cafés were the first site to change. The arrival of battery-powered radios, later cassette recorders, and now television has pushed out the poets and their stories. ${ }^{4}$ At weddings it is no longer considered chic to bring in a poet or poets. As recently as the I970s, villagers recount, a wedding was hardly a wedding if there was no poet to sing the deeds of the heroes of the Bani Hilāl tribe after the traditional wedding songs and rituals had taken placeand the performance had to go on till the dawn call to prayer to be a good one. Now many villagers prefer to hire a singer with an amplified band who sings a mixture of traditional rural wedding and religious songs along with renditions of songs by famous urban singers such as Umm Kulthūm and 'Abd al-Halīm Hāfiz. Private parties featuring poets are becoming rarer and rarer as the elder generation, those who still most appreciate the epic, passes on. The poets of al-Bakātūsh currently live mostly from their circuits of patrons, a few weddings, private gatherings, and "vagrancy."

The following discussion of performance contexts concentrates on three sets of features: (a) economic structures, that is, means of payment, patronage structures, $(b)$ customary performance characterstics-choice of repertoire, use of auxiliary genres, and so forth, and $(c)$ the attitudes of villagers and poets toward the context itself.

\section{Weddings}

The process of engagement and marriage in al-Bakātūsh, as in most of Egypt and the Arab world, unfolds in a sequence of ceremonial stages,

3. For nineteenth-century sources on performance of Arabic oral epics see Lane, Manners (I895); Yūnus, al-Hilāliyya; and Breteau, "Témoinages."

4. For an evocative description of the transformation of a café from a site for epic performance to a media-dominated context, see Naguib Mahfouz, Zuqāq al-midāqq (I 947), 7-I2; idem, Midaq Alley, trans. Trevor LeGassick (198I), 3-7; part of this translation is quoted at the opening of this chapter. 
often spread out over several months or even years. These include the Reading of the fatiha (al-fatiha), the Writing of the Wedding Contract (katab al-kitäb), the Presentation of the Dowry (shabka), ${ }^{5}$ the Night of Henna (laylat al-hinna, $S A$ hinna $\left.\bar{a}^{2}\right)$, the Carrying (al-shayla), the Procession (al-zaffa), the Consummation, literally, 'the Entrance' (al-dukhla), and the Morning Visit (al-subhiyya). ${ }^{6}$ Each of these takes place on a separate occasion and is marked by traditions and ceremonies, several of which include music in the form of traditional songs or professional entertainment. The prime context for the performance of Sìrat Banì Hilàl occurs on the Night of Henna, which is usually the largest of the public celebrations, but on occasion poets may be called in for the Presentation of the Dowry and the nights leading up to the Night of Henna by families who wish to make a particularly notable event of the occasion.

On the Night of Henna the bride and groom are separately prepared for the wedding's culminating ceremonies, which take place the following day. In their respective groups of relatives and friends, they are bathed, their hair is trimmed and coiffed, they are dressed, and each is physically adorned with henna. In the case of the groom in al-Bakātūsh, the latter is usually decorated only on the palms-in each hand he holds a lump of henna mixture which will dye his palms bright orange. Once the groom has been bathed and freshly attired, he is led outside with much festivity and seated on a chair on a platform, while relatives and friends celebrate around him. A parallel celebration takes place around the bride, though this is held indoors.

The traditional songs sung at this point of the wedding reflect not only the activities that are being carried out at that moment but the entire complex of behaviors linked with marriage. Perhaps the most common wedding song in all of Egypt, with its myriad of different verses, is "The Henna, the Henna" (al-hinna, al-hinna). It is most commonly sung by women as they dress and coif the bride, though it is

5. Western terminology of dower, dowry, and brideprice does not of ten clearly distinguish between payments made from the groom to the bride and payments made from the bride to the groom. In the Egyptian case, substantial payments are made to the bride by the groom in the form of gold jewelry, which becomes the bride's private property and remains hers even if she is widowed or divorced. It could be considered a form of social insurance. The groom also provides housing and basic furniture; the bride brings into the marriage her personal belongings and all the household effects necessary for the beginning of their domestic life (linens, kitchen utensils, etc.).

6. The various rituals and traditions surrounding engagements and weddings differ in detail from region to region, though most follow this general pattern. A mark of both the diversity of these ceremonies and the importance attributed to them may be seen in a weekly radio program that has run for several years on the Voice of Cairo (\$awț al-qāhirah) radio station. The program discusses wedding rites and customs from around Egypt and the Arab world. Several of my close friends in al-Bakātūsh avidly followed this program throughout my stay. 
heard and well known by the men as well. The recurring interjection "O my eye!" ( $y \bar{a}$ ' ayn $\bar{\imath})$ is a reference to the eye as the seat of emotion and love in Arabic poetry (along with the heart, the soul, and the liver):

The henna, $\mathrm{O}$ the henna, $\mathrm{O}$ drop of dew,

$\mathrm{O}$ the window of my beloved, $\mathrm{O}$ my eye, brings [a breeze] or [love]. ${ }^{7}$

O how I fear your mother when she asks me about you,

I'll hide you in my eyes, $\mathrm{O}$ my soul, and put kohl over you.

O how I fear your sister when she comes looking for you,

I'll hide you in my hair, $\mathrm{O}$ my eye, and pleat it over you.

And if evil-speakers come to me and ask me about you,

I'll put you in my breast, $\mathrm{O}$ my soul, and cover you with pearls." ${ }^{8}$

al-ḥinna [SA hinnā'] yā l-ḥinna yā qațr al-nadā, yā shubbāk habīīī, yā caynī jallāb al-hawà

yā khawfì min ummak lammā tas'alnī calayk, la-aḥutțak fì caynī, yā rūhịi, wa-ukaḥhil 'alayk yā khawfì min ukhtak lammā tudawwir calayk, la-aḥutțak fì sha' ${ }^{\prime} \bar{i}$, yà caynī, wa-uddaffir calayk. wa-in ja'atnī al-'awāzil [SA ‘awādhil] tas'alnī 'alayk la-ahuțțak fî șadrīe yā rūhịi, wa-l-lūlī [SA lu'lu'] 'alayk ${ }^{9}$

The song refers not only to the activities of the night of henna (putting on kohl makeup, braiding the bride's hair, putting on jewelry) but also to the behavior demanded from the bride - that she display no emotional involvement in the proceedings. The bride must traditionally appear distant and even morose; her muted emotions must display sadness at her departure from her family home, and she must show no happiness or joy that might be construed as anticipation of the sexual act which will initiate her into womanhood. She must conceal her emotions, metaphorically described in the song as hiding her beloved.

7. The colloquial Egyptian word hawa conflates the classical Arabic words for both "love" (hawa) and "air" or "breeze" (haw $\vec{a})$. See Hinds and Badawi, Dictionary of Egyptian Arabic.

8. Text adapted from Baheega Sidky Rasheed, Egyptian Folk Songs (I964), 8 (my translation). There are literally hundreds of verses to this song, many of which are made up spontaneously at weddings and are then passed from wedding to wedding and region to region. A similar pattern for improvisatory singing is found in the song "Aț̣hhān yā șabāyā" "I am thirsty, O maidens', which is used in many different contexts and to which famous poets and singers have created versions ranging from the highly political to sarcastic parodies of the original.

9. This transcription presents standardized vocalizations and spellings consonant with Modern Standard Arabic, with the exception of those lexical items glossed in the text. 
The song also refers to traditional village ideas about public relations between men and women before marriage. If a woman does indeed love her future husband, no one must know, for it may lead to accusations of misbehavior. In front of the groom's mother and sister she should appear indifferent, hence her fears about successfully hiding her emotions. In addition, she must fear the 'awazzil (sing. ' $a z \bar{u} l$ ), who are a major concept in Egyptian folk poetry, translated here as "evil speakers. "10 They are people who strive to separate couples in love by creating rumors and gossip which effectively doom their chances of getting married. They do so out of jealousy, envy, and pure maliciousness. In a tightly knit society such as the village, "people's talk" (kaläm al-nās) is a powerful social force and one to be reckoned with.

The imagery of the song thus indexes ( $\mathrm{I}$ ) the intimacy and possessiveness of young love, (2) the activities involved in preparing the bride, (3) the bride's struggle to conceal her feelings and emotions and to maintain the expected passive demeanor, and (4) the necessity of publicly dissembling any affection or desire she may feel for the bridegroom.

As the culminating portion of this celebration, when all the other ceremonies have been completed, poets are brought out to entertain the guests. It is a cliché in al-Bakātūsh that they should sing "until the dawn call to prayer."

For the poets, weddings constitute the most respected context for their art. Private gatherings of aficionados might be more challenging and more rewarding in personal ways, but it is at weddings that the poets reach their largest audiences and most strongly establish their public reputations. Wedding performances almost invariably take place out of doors, with the poet of ten performing on a rough platform or stage, and sometimes beneath a canvas pavilion. At weddings, poets almost always perform in pairs, for the audience demands constant

Io. From classical Arabic 'adhūl 'rebuker' or 'critic'. Hinds and Badawi, Dictionary of Egyptian Arabic, 576: "jealous person who attempts to interfere between intimates or lovers." The role of the slanderer/reproacher who seeks the rupture of a love affair has been part of the Arabic tradition of love poetry since the earliest periods. It has been suggested that this figure is one of many motifs associated with "courtly love" which passed into European tradition during the seven hundred years of contact with Arabic literature and culture in medieval Arab Spain, Arab Sicily, and during the Crusades.

For the history of the 'adhul and other features of Arab "courtly love," see Alois Richard Nykl, Hispano-Arabic Poetry and Its Relations with the Old Provençal Troubadours (1946); Lois Anita Giffen, Theory of Profane Love among the Arabs (197I); Linda Fish Compton, Andalusian Lyrical Poetry and Old Spanish Love Songs (1976); A. Kh. Kinany, The Development of Gazal in Arabic Literature (I95I); and for criticism of studies concerning literary contact between Arab Spain and medieval Europe, see Maria Rosa Menocal, The Arabic Role in Medieval Literary History (1987). 
entertainment. Usually only one poet will sing the epic itself while the second accompanies him on the rabāb and periodically sings other types of material so the lead singer may rest.

A poet may earn more at a single wedding than several weeks, perhaps even months, of other types of performances, for not only is he paid by the family involved, but he receives gifts of money (nuqat or nuqūt) during his performance commensurate with the audience's appreciation and approval.

Nuqūt (sing. nuqta) are literally "drops," as of water. The term refers to small gif ts of money given to the bride and groom at weddings, to children at births or circumcisions, and to musicians at performances, particularly in return for public greetings or salutations. On the Night of Henna the groom's barber is also present, usually seated next to but lower than the groom, and receives nuqūt as well. Though barbers receive semiannual payments from families in return for cutting hair and shaving the male members of the family, their largest profit is derived from wedding payments which accumulate into a considerable sum by village standards.

Nuqūt paid to the bride and groom are carefully recorded in a register, for they must be paid back in equal amounts at future weddings involving members of the giver's family. The entire system is a complicated economy of exchange which may provide newlyweds with several hundred dollars worth of gifts with which to begin their domestic life, all of which is then paid back in reciprocal gifts over the years.

Poets' families do not ordinarily give nuqūt at villagers' weddings, nor do villagers off er nuqūt at poets' weddings. Poets do, however, as mentioned earlier, receive nuqūṭ as performers. Audience members are at times moved purely by the excellence of certain moments in the performance to approach the poet and offer him a small amount of money or cigarettes, which is almost always acknowledged verbally by the poet, of ten in verse. More often, however, audience members hand small amounts to poets in return for public salutations to the bride and groom and their respective families, or to notable guests in the audience. The poet in this way acts as the official mouthpiece for public greetings and compliments paid back and forth between families and friends. These salutations are a means of calling attention to one's attendance at the celebration, an act that is an acknowledged duty (wajib) in village society, and a means of negotiating relationships among individuals, families, and clans in a public forum. The outsider status of the poet, the neutral intermediary, greatly facilitates such social negotiation. Traditional weddings thus act as moments for the transference of sizable economic resources from the larger community to (I) newlyweds, (2) poets, and (3) barbers. 
Though the epic singer may always function to some extent as a crowd-pleaser and as a reflection of his audience's tastes and preferences, different contexts do, in fact, engender different critical relationships between the performer and his listeners. These relationships are ones the poets openly acknowledge and discuss among themselves. Such private discussion is often couched in the form of advice presented to younger performers and constituted one of the richest veins I was able to tap during my "apprenticeship." I consistently found that although I could never act as a true apprentice in many respects (particularly as a nonnative speaker of Arabic and as someone who had not absorbed the complex narrative elements of the epic in childhood), I could act successfully as a catalyst for discussions about the ways of dealing with different types of audiences in different contexts, the sorts of episodes to perf orm when, the preferences of different social groups for sad versus comic sections of the epic, and so on. In such discussions the poets of alBakātūsh stressed the following characteristics of wedding performances:

* The episode chosen should be a light and happy one from the epic, preferably one that ends in a wedding (examples include "The Tale of Shāma, Queen of Yemen" and "The Tale of the Maiden Badr al-Șabāh"). At weddings the poets are rarely asked to perform a specific episode and thus are usually free to present a story they feel is appropriate for the celebration. Should a patron request a certain section of the epic, however, poets almost always acquiesce. The final wedding scenes within such episodes can be elaborated and manipulated so as to include blessings and best wishes for the bride and groom and their families. The same scenes when performed in private sahras rarely take more than a few verses to describe.

* At a wedding performance one should not begin singing the epic until at least midnight, when all the other singing and dancing has died down. In this manner, whoever wants to listen can listen, and the others can go home. Several times I was told that the commercial star, Sayyid Hawwās, never sang from the epic before one o'clock in the morning, after his son had already played for an hour or so to warm up the audience.

$\star$ The poet should intersperse the performance regularly with praise songs to the Prophet (madīh), comedy routines (hitat baladī), lyric pieces (mawāwìl, sing. mawwāl); and (adwār, sing. dōr), and the like. People at weddings want to be entertained, "and that is what is required of us" (wi-dā huwwa l-mațlūb minnā..)

I might add one further element to this list based on my own observa-

II. Shaykh 'Abd al-Wahhāb Ghāzī, 3/I8/87. 
tions rather than on specific statements by poets. At wedding performances, poets usually do not argue with audience members about details of the story or any other disputed aspect of the performance; if an audience member disagrees with him, the poet often cedes the point in the greater interests of the celebration. If there are requests for other materials such as mawāwìl or hitat baladī, the poet will generally comply. Since the story of the epic, particularly in the early part of the performance, is of ten interrupted by the presentation of nuqūt and accompanying salutations, there is little objection to further interruption for the performance of other materials. Whatever sense of authenticity the poet may evince in other contexts, whatever personal sense of loyalty he may posses to the tradition as he has learned it, this is usually suppressed in wedding performances so as to avoid conflict. ${ }^{12}$

Wedding performances possess an additional feature which strongly marks them: they represent one of the few contexts which female listeners and children may attend freely and openly. Although the listeners seated immediately in front of performing poets are almost invariably adult and male, on the edges of this central group, on porches, balconies, rooftops, and other marginal spaces, female listeners also assemble. Children at weddings are of ten running about and playing, but performances of epic are primarily late at night when the number of children still energetic enough to cause a disturbance is small. The children are, in any case, kept out of the area occupied by the adult men.

One result of this heterogeneous audience is that certain highly erotic sections of the epic are avoided or toned down during wedding performances (such as "al-Jāzya at the Wall of Tūnis"; see Chap. 5), or are performed, at minimum, with heavy censorship and repression of certain lines and jokes. This suppression of erotic themes is in direct contrast to some of the other elements of the celebration. The songs sung by the young, for the most part unmarried, men at weddings are almost all highly erotic and bawdy in nature. ${ }^{13}$ (I have no parallel knowledge of the songs sung by the women celebrating round the bride.) The comic potential of the epic, on the other hand, seems to be routinely highlighted and emphasized at such large, outdoor performances.

Despite the increasing popularity of urban-style music at village weddings, an interesting set of circumstances can conspire to promote epic poets at weddings, at least temporarily. When there has been a recent

12. For references to the critical discussions within epic performances, see Taha Hussein, An Egyptian Childhood (1982), 2; and Slyomovics, Merchant, I IO-II.

13. Typical songs sung by the young men include "Why Have All the Girls Gotten Married?" (Kull il-banāt itgawwizū lēh?), "What Is This Boy Scared Of?" (Il-wād dā khāyif lēh?), "I'm Thirsty, O Maidens" ('ațshān, yā șabāyā), and others. 
death in the village where a wedding is planned, and family members are still sitting the first seven days of mourning, it is considered disrespectful and inappropriate to have loud amplified music. In this case people of ten bring in the epic poets as a substitute form of entertainment. Even if they are less chic, they are traditional, and since they can perform without loudspeakers, the wedding may take place as planned.

A special atmosphere thus pervades the wedding context, one that demands light-heartedness (khiffat damm, lit. 'lightness of blood') and joy (farah). The most common word in al-Bakātūsh for wedding is in fact farah 'joy'. ${ }^{14}$ This does not mean there will be no drama or tragedy in the performance. On the contrary, almost all episodes from the epic contain deaths of heroes and painful reversals of fate. A number of episodes, in fact, deal almost exclusively with the death of a major hero. The requirement is only that the tale resolve happily, preferably with a wedding scene. The "The Tale of Handal al-CUqayli," for example, is considered a light (khafif) tale for it resolves happily and is easy to sing, though it also contains the deaths of the fathers of the main heroes at the hand of Handal during his treacherous night-raid on the Hilāli camp. It is not, however, considered particularly appropriate for a wedding for it does not end with a great wedding scene. ${ }^{15}$ Such wedding episodes are considered preferable for they have numerous comic sections and conclude with the desired wedding motif.

One wedding occasion outshines all others as a context for Sirat Banī Hilāl: the wedding of a poet's son, when epic singers from all over the Nile Delta come together to celebrate. Traditionally on these occasions there are no recitations of complete episodes, but rather, poets take turns performing highlights from the epic, striving to outdo each other in humor, pathos, or eloquence. The accounts of several famous weddings of poets figure prominently when the al-Bakātūsh poets discuss great poets and performances of the past.

Clearly no other desired experience could have figured higher in my hopes during fieldwork than to attend such a wedding. Two in fact took place during my I986-87 stay and I was invited to each. The first was to take place in al-Buhayra Province, west of the Nile. Three weeks before it occurred, however, another poet's family in the same community celebrated their son's circumcision with a large celebration. At this

I4. The term may refer to either the shabka or laylat al-hinna (the two large festivities) and is thus tied to the idea of the public celebration of nuptial rites.

I5. Two characters do in fact get married at the end of the tale, but they are very minor figures; the celebration at the end of the tale is for the return of the hero, Abu Zayd, who had been thought dead, not for the acquisition of a new bride by a Hilāli hero or for the reunion of two separated lovers as in the other typical wedding episodes. 
celebration a fight broke out which rapidly degenerated into a grand melee; shots were fired, the police were called, and several participants landed in jail. As a result, the al-Bakātūsh community decided not to attend the wedding en masse, but rather to send a single male representative from each household. I was asked not to attend.

The second wedding took place in al-Bakātūsh itself, and, as it fell toward the very end of my stay in the village, it seemed the perfect culmination to a year of fieldwork. To my initial surprise, however, the groom's uncle insisted that the entertainment be an amplified band from the provincial capital of Kafr al-Shaykh. Though everyone enjoyed the modern glow of the celebration, at the wedding meal a heated argument broke out about the use of a band rather than epic singers for entertainment. The dispute wove back and forth between the desire to show the larger community that they were not backward or too poor to have citystyle music and the desire to maintain the tradition of a large gathering of singers to mark a poet's wedding. Emotions ran high, and eventually several men who most strongly supported the traditional wedding stood up and left. ${ }^{16}$

A wedding still constitutes the most respected context for the performance of Sìrat Banī Hilāl in al-Bakātūsh. As a performance context it has intrinsic constraints, and it dictates a specific performative framework. Furthermore, weddings represent a major financial resource for the poet community and also embody a specific style or mode of performance which every successful poet must master.

\section{Circumcision Ceremonies}

Grand, public celebrations of a son's circumcision-celebrations large enough to merit the hiring of a poet-are rare and restricted to families of considerable financial means. (Traditionally circumcision ceremonies were carried out when the son was anywhere between a few months to nine years old, but in recent years they have been held most of ten well before the son reaches the age of five or six.) The performance setting is quite similar to that of a wedding in that the occasion is large, public, and held outdoors, and payment is received from both the host family

I6. In the period between my departure in 1987 and a later visit in 1988 , no poet weddings had taken place, so it remains uncertain how the community will choose to celebrate these occasions in the future. It is possible that the wedding described here marked the loss of a major performance context, particularly since the sons of poets whose weddings are now being celebrated are not themselves performing poets. These young men have much more tenuous attachments to the epic singing tradition, and a number of them regard it as a disreputable aspect of their families' past which they would prefer to ignore completely. 
and from listeners. The latter contribute in the form of nuquatt. Again, auxiliary genres are frequently used to liven up the festivities, and similar constraints of propriety are maintained in view of the mixed audience.

No episodes in the epic recount the circumcision of young heroes or their sons, so the poets' preferred choice of scenes for a circumcision is to sing an episode or sequence containing acts of heroism by one of the main heroes or one of their sons. Their motivation for singing about acts of heroism as part of a ceremony marking a boy's symbolic entrance to manhood and to fuller participation in the religion of Islam seems clear: the poets consciously sing about heroes in order that young people may learn by example. This idea is also reflected in testimonies by audience members about the importance of the epic.

\section{Cafés}

The epigraph at the beginning of this chapter exemplifies the disappearance of the café or coffeehouse as a context for Sìrat Banì Hiläl performance. Although that scene was set in Cairo in the early I940s, similar scenes, according to the poets of al-Bakātūsh, were occurring in their region by the late I96os. Prior to that period poets could depend upon a warm reception and an opportunity to sing for an evening or more at cafés that regularly attracted epic poets. Poets would set out from their home villages on circuitous routes through the Nile Delta region, stopping at cafés, at the villages of known patrons, and exploiting whatever other opportunities turned up.

Upon a poet's arrival in a village, his rabāb would be hung on two nails over or near the door to the café to indicate that there would be epic singing that evening. Though the café owner might pay the poet a small fee, more of ten he only fed him, supplied him with tea and cigarettes, and sometimes housed him during his stay. Either listeners handed the poet small gif ts during the performance or a small bowl or other container was set up near the door and patrons dropped in a few coins as they came or left.

The following description, given by Edward Lane of coffee-shop performances of Sìrat Bani Hiläl and other siyar in Cairo during the I 830 s, is echoed by descriptions given me in the I 980 s by al-Bakātūsh poets:

Reciters of romances frequent the principal kahwehs (or coffee-shops) of Cairo and other towns, particularly on the evenings of religious festivals, and afford attractive and rational entertainments. The reciter generally seats himself upon a small stool on the mastab'ah, or raised seat, which 
is built against the front of the coffee-shop; some of his auditors occupy the rest of that seat . . most of them with the pipe in hand, some sipping their coffee, and all highly amused, not only with the story, but also with the lively and dramatic manner of the narrator. The reciter receives a trifling sum of money from the keeper of the coffee-shop, for attracting customers; his hearers are not obliged to contribute anything for his remuneration; many of them give nothing, and few give more than five or ten faddahs. ${ }^{17}$

One interesting aspect shared by both coffeehouses and patronage circuits is that audiences in particular locales apparently of ten ask the visiting poet for the same episode, year after year-perhaps owing to the pleasure of knowing and anticipating the story, perhaps owing to an association built up between certain poets and certain tales. Several of the al-Bakātūsh poets mentioned this phenomenon, which they chalk up as one of the quirks of the fellähs 'peasants', 'villagers'. Another characteristic attributed by poets to the fellāhs is their supposed inability to remember the names of characters other than the main heroes. Poets of ten joke about the villagers' manner of asking for a particular episode ("Sing the story where Abu Zayd's son goes out to fight and then doesn't obey his father and he sends him on a journey to punish him,") rather than referring to the main character or to the "title," such as "The Story of Badr al-Sabāh," as the poets do.

One key characteristic of the café context which is now only extant in the sahra, which we examine in some detail when considering audience/ performer interactions, is a sense of defending the integrity of the epic tradition. In most performance contexts, poets, when challenged about some aspect of their performance, will accommodate the audience's point of view to some extent, though they may comment on it and even laugh and joke about it afterward. In the sahra, and this was apparently true of the café as well, the poet assumes he is addressing a knowledgeable audience, "those who have an understanding of the epic" (illi biyifhamū fi l-sira), which sets up a markedly different dynamic between poet and audience, one which supports and even thrives on criticism and discussion.

\section{Patronage Circuits}

During my fieldwork (1983, 1986-87, 1988), patronage circuits still represented the largest single source of performance income for the poets

I7. Lane, Manners, 386. 
of al-Bakātūsh. In a number of poet families, income from the activities of wives, daughters, and nonperforming sons has equaled or surpassed that brought in by the poet head of household. This was apparently not true in the past, though these additional sources of income may always have been essential. Commercial activities of other family members currently include buying and selling vegetables in the local markets and trading odds and ends such as plastic kitchenware and inexpensive tshirts and socks. Various labor arrangements involving sons range from apprenticeships in nonpoet crafts to full-time employment in such occupations as carpentry, construction, plumbing, and even the police force. Such alternative employment for sons has only existed as a major factor in the economic life of the community for the past ten to fifteen years, according to the poets.

Relationships with patron families whom the poets of al-Bakātūsh visit have for the most part been maintained over several generations. As mentioned earlier, patron families are usually visited twice a year during the periods immediately following the major harvests. The poet's role of entertainer at the harvest festivities was probably at the heart of the patronage system of which we can observe only sparse remains today. Many narratives of past performances recounted by the poets (such as those presented in Chapter 2) include descriptions of poets arriving in time for the end of harvest celebrations at which they would then perform. These descriptions, however, are of the period before the Nasserite land reforms of the I950s, which broke up major landholdings and redistributed them to the fellahins. There are no longer estates of hundreds and thousands of acres which require small armies of workers, and thus there are no longer enormous celebrations to which the poets are summoned to perform. Here, by contrast, is the summary of an account of a contemporary visit:

Shaykh Ṭāhā and his eldest son, al-Sayyid, went on a four-day trip to an area near Sìdī Sālim to visit nās habāyib (literally 'people who are loved ones', that is, patrons). Shaykh Țāhā recounts that they arrived about ten in the morning and the men were out planting rice, but the women greeted him by name and told him to come in and sit, telling him, "You're not a stranger! The house is your house! Come in and sit!" They sang for two nights and received six kila of wheat ${ }^{18}$ and four packs of cigarettes (above and beyond what they were given during the two nights and smoked there). During the two nights they performed they also received nuqūt (i.e., from the audience). The family slaughtered chickens and ducks

I8. One kìla $=$ I $/$ I2 ardabb; I ardabb $=5.45$ bushels; thus, 6 kìla $=$ approximately $2^{3 / 4}$ bushels. 
for them. They have been going to this family since before Shaykh Țāhā's father's time. ${ }^{19}$

As with narratives of past performances, these accounts of recent travels consistently reiterate several key motifs: ${ }^{20}$ first, the poet and his son were going to visit "loved ones" or "friends"; second, these people knew their visitors by name; third, they were welcome (so welcome and trusted in this case that they were ushered into the house, even though the menfolk are not present); and fourth, their patrons were generous. These recurring motifs all seek to preserve the same essential distinction-the difference between visiting a patron's family and begging or vagrancy.

The "greeted-me-by-name" motif in particular is extremely common, for it is by this particular topos that the poets distinguish in their narratives between traveling done on their patronage circuit from traveling done in search of any opportunity to sing. The first is totally respectable; the latter smacks of vagrancy.

The lack of harvest celebrations is not the only aspect of the patronage circuits which has changed. One poet confessed that in recent years, his patrons have asked him to sing less and less often. Nowadays, he said, he ended up watching television with them as of ten as he sang-but they still give him remuneration as before.

I was never able to speak with the head of a family that was currently patronizing one of the al-Bakātūsh poets, though I was three times able to speak with sons of men who had or still did patronize epic poets. The first felt that his father genuinely loved to listen to Sirat Bani Hilàl, though he, the son, did not care for it much and usually left the house when the poet began to sing. The second, however, felt that his father continued to patronize the epic poet who visited them once or twice a year out of a feeling of duty: it was something that his father before him had done, and the poets are, after all, needy (ghalbānin). ${ }^{21}$

This second viewpoint was upheld and clarified by a folklore researcher in Cairo whose father had patronized not only poets but dervishes and sufis. The researchers felt his father did not do so out of any real interest in poetry, yet he put aside a portion of his crops every year for these groups. The reseacher felt his father's desire had been to preserve

19. Summarized from Shaykh Tāhā's account, 7/9/87.

20. I elicited these accounts. They are not an acknowledged genre, although they turn up regularly in narratives of "past performances" recounted commonly during breaks in sahra performances.

2I. The term ghalbānin is used to express a spectrum of ideas ranging from wretched and poor (in worldly terms) to unfortunate or miserable (in emotional terms). 
somehow the "balance" of society, that these marginal groups represented something that should continue, a tradition to be preserved. ${ }^{22}$

In a hamlet about an hour's walk from al-Bakātūsh, a friend recounted that a long time ago his father had patronized a poet for several years. This relationship grew not only from the father's love of Sirat Banī Hiläl but from an incident in his life. When the son was still very young, the father fell ill and was bedridden for several months. During that time he sent for a poet to come and live with the family, and to play for him in the early morning when he first woke up and late at night as he went to sleep. At other times of the day the poet would sing and entertain, but in the morning and late at night he was asked just to play the rabāb. In 1987, nearly thirty years later, the father, now in his eighties, could still recite for me lengthy sections of the epic from memory. ${ }^{23}$

Though the demand for actual performances is dwindling, the income the poets derive from this system does not seem to have dropped off drastically. Some of the patron families seem to share a will to secure for these traditional artists a basic livelihood with a certain amount of dignity, even when the art form they purvey is less and less in demand. The patronage circuits are a respected context for performance of Sirat Bani Hiläl, with one drawback: they must be carefully distinguished from "vagrancy," for a poet leaving the village with his rabāb on his shoulder to visit a patron looks exactly like a poet going to the nearest town to play in the marketplace. The motifs of being greeted by name and being ushered into homes as honored guests serve not only to build the image of the poet as respected artisan, but also to differentiate between what the poets know in the outside world are judged to be licit versus illicit sources of income.

\section{Saints' Festivals}

The poets of al-Bakātūsh attest that there is no longer an audience for Sìrat Banī Hilāl recitation at the saints' festivals (mawälid; SA sing. mawlid, EA mülid) of the Nile Delta region. At first this seems surprising, for the festivals attract to a great degree the same traditionally oriented social groups who constitute the most enthusiastic patrons of the epic. Furthermore, the festivals occupy a focal role in the religious life of the rural areas of the Delta. Al-Bakātūsh is within an hour's drive of the two largest festivals in northern Egypt, that of al-Sayyid al-Badawì in Tanța, and that of Ibrāhīm al-Disūqī in Disūq, and there are practicing Sufi

22. Conversation with 'Abd al-Hamīd Hawwās of the Folklore Institute in Cairo, 7/5/87.

23. Father of 'Ișām Abū Humayd, hamlet of Abū Humayd. 
brotherhoods in al-Bakātūsh from the orders of both al-Badawī (the Badawiyya order) and al-Disūqī (the Brahimiyya or Burhāniyya order). ${ }^{24}$

The festivals are now dominated, however, by performers using urban-influenced performance styles-singers with large ensembles and loudspeakers. Instruments present at a mūlid currently include violin, lute (' $\bar{u} \mathrm{~d})$, electric keyboard, and accordion, none of which exist commonly at the village level of "folk" music. Performers include shaykhs (mashāyikh) who sing moral song-tales, munshids who sing praise songs to the Prophet Muhammad (madh al-nabi or madih ), and accounts of the lives of the Sufi saints, as well as singers (who may also be called munshids) attached to local Sufi brotherhoods who exclusively lead dhikrs (the musically accompanied repetition of one of the names of God or other short phrases which forms the heart of Sufi worship) and do not sing any of the longer narrative genres. ${ }^{25}$

Saints' festival celebrations have over the past few decades evolved toward a more modern, amplified, louder, soundscape. The traditional poet, singing solo or with a single accompanist, would undoubtedly sound thin and out of place. Although Edward Lane, in his description of Cairo in the I830s, states that during the nights of religious festivals, epic singers performing at coffeehouses were particularly common, he does not mention epic singers performing out in the squares, the streets, and the open spaces that form the heart of the festival. It appears that even at that time, epic singing may have taken place on the margins of the overall celebrations, in smaller, enclosed spaces rather than in central, open spaces.

Though performances of this kind may still occur in other areas of

24. For descriptions of the Sufi brotherhoods and their festivals see J. Spencer Trimingham, The Sufi Orders of Islam (197I); Joseph W. McPherson, The Moulids of Egypt (I94I); Annemarie Schimmel, Mystical Dimensions of Islam (1975). For a fictional and moving account of the alSayyid al-Badawi festival, see the novel Ayyām al-insān al-sabca (The seven days of man), by 'Abd al-Ḥakìm Qāsim (n.d.); a summary and analysis of this work in English can be found in Roger Allen, The Arabic Novel (1982), I 20-3I.

25. These categories are not mutually exclusive; they are, however, the common terms and associated repertories used by the inhabitants of al-Bakātūsh. Much work is still to be done on the various genres associated with folk Islamic practice in living tradition. The moral song-tales of the shaykhs (qișașal-mashāyikh], for example, are perhaps the single most common genre of musical entertainment at festivals and celebrations but have received little attention from Western or Arab scholars. For the munshid tradition, see Waugh, Munshidin (1989). Although this work is marred by numerous errors, it is at least a sympathetic introduction to the practitioners of modern Sufism and their art forms.

An additional category, not fully separable from either the mashāyikh or the mushidin, is that of maddāh, literally 'one who sings madīh'. In the region of al-Bakātūsh, this seems to imply a less accomplished singer, usually performing alone, who cannot lay claim either to a particular level of religious education or to the level of musicianship associated with singers who perform with full ensembles. 
Egypt, and there is some evidence that this context may still be alive in Upper Egypt, in the Nile Delta Sìrat Bani Hilal appears to have irrevocably lost its place in the celebration of saints' festivals.

\section{"Vagrancy": Squares, Trains, Fields, Marketplaces}

From the viewpoint of the most villagers, the presence of the poets in al-Bakātūsh is uncomfortable because of their Gypsy origins and because of their association with tasawwul-vagrancy and begging. Indeed, all of the images and stereotypes propagated about the poets by the outside world relate to these two central issues. The villagers consider any uninvited performance "vagrancy." And this in turn means that the poets' income is always suspect, for it is always tainted with the possiblity of illicit provenance.

Trains, marketplaces, town squares, the edges of fields, and numerous other locations are all possible sites for performances. The income derived from these performances is minimal; however, it tides the poets over between other performances and as such plays a critical role. This type of performance, since the disappearance of the café circuits, is the only performance context fully controlled by the poet; all other contexts are contingent upon either the time of year (for visits to patrons) or an invitation to perform. This issue of control may in fact be the underlying cause of the deep-rooted antipathy villagers feel for these performances.

Such performances are marked by a strong reliance on the religious portions of the poets' repertory; rarely do they sing from the epic in these performances. There is no question of maintaining the integrity of the epic tradition here; these activities are undertaken with a single purpose-to earn money. The performances carry great psychological weight with the other inhabitants of al-Bakātūsh: The shame of the "beggar" poet is the counterweight to the fame of al-Bakātūsh as residence of the region's best singers of Sirat Bani Hiläl.

\section{The Sahra: Private Evening Gatherings}

The sahra or $l \bar{e} l a^{26}$ is one of the fundamental evening pastimes of village men, from adolescence onward. It connotes time spent with companions in the evening or nighttime, usually with some diversion

26. The word lèla (SA layla) literally means "night," and the two terms are used interchangeably in the sense of an evening gathering; however, since lèla denotes a number of different things as well (night, Fate, a girl's name, etc.), the unambiguous term sahra is used throughout this work. A third though less common term used in the village is haflit samra 'an entertainment party', which usually implies a larger, more organized activity than just a sahra of friends. 
or pastime as a focal point. The verb sahara ${ }^{27}$ may be used to designate time spent in cafés or other public places playing backgammon, listening to the radio, watching television, conversing, smoking on the gozza 'waterpipe', or simply staying awake late. Saharnā sawà means "we spent time together in the evening/night." But the noun, sahra, refers to a gathering that has been organized to some extent, for which there is a host and a venue. In the context of the village, this term invariably refers to a gathering held in someone's home. The same activities may take place (backgammon, television, etc.), but drinks such as tea, juice, hibiscus infusion (karkade $)$, or sweetened salep drink (sahlab), and possibly food, are offered throughout the evening by the host. In addition, the host may provide entertainment in the form of a poet singing an episode from Sìrat Banì Hilall. The host may pay a flat fee to the poet, or it may be understood that the guests are to contribute nuqūt as in other performance contexts. In any case the poet is offered numerous cigarettes by audience members, who place them directly in front of the poet or off to one side.

Only a handful of men in al-Bakātūsh now host such performances of Sirrat Bani Hilāl with any regularity. The friends they gather round them at these parties are almost always fellow enthusiasts of the epic tradition, though there are usually a few men in any such gathering who are not as well acquainted with the epic as the core group. These latter tend to take little part in the debates and discussions that break out frequently-this is not their bailiwick, and they usually defer to the acknowledged devotees in conversations about the performance.

The sahra represents the one contemporary context where the poets feel they are performing for aficionados of the tradition, although this is not always true, for the group may be constituted primarily of young men who are seeking more entertainment and pleasure than "authenticity." But at a sahra, even a lighthearted and convivial one, a listener may challenge the poet for having left out an important element, for having forgotten a certain passage, for having made a mistake, and the poet in this context (depending on whether he deems the point valid or not) will counter with a defense of his version, or amend it in light of a correction he thinks sound.

The performance structure of the sahra is quite stable. ${ }^{28}$ After initial greetings, a glass of tea, and a cigarette, the poet unwraps his rabāb and

27. Not to be confused with the root $/ s \underline{h} r /$ with emphatic/ș/ and pharyngeal / $h /$ which generates the word "desert" (șahrä, pl. șahârăa), the origin of English "Sahara."

28. The description which follows and numerous references over the next chapters are culled from seventy-six recorded sahrāt and several unrecorded performances, all from my I986-87 stay in al-Bakātūsh. Performances from I983 or I988 are specifically cited as such. 
begins to warm up by playing short instrumental passages. He then opens the performance with a praise song to the Prophet Muhammad (madih), usually one that recounts an event from his life such as "The Prophet and the Gazelle," in which the Prophet saves a mother gazelle from a hunter by offering himself as ransom; this acts so moves the hunter that he converts to Islam. ${ }^{29}$ The poet then stops playing the rabāb and in rhymed prose rapidly sets the scene for the episode the audience is about to hear. He might explain where in the epic this episode occurs and which adventures have already taken place; sometimes he introduces the main characters. He breaks off the rhymed prose at a point when one of the characters is about to speak; then the poet admonishes his listeners to harken carefully to his words, and, after all have wished God's blessings on the Prophet Muhammad, the character begins to speak. This speech is the speech of heroes-rhymed epic verse, sung to the accompaniment of the rabāb.

At this point we have moved fully into the domain of epic-singing proper. Once there, the narrative voice, characters' voices, and asides to the audience are nearly always in sung, rhymed verse. At intervals the poet stops and narrates a brief section in rhymed, spoken prose (with no musical accompaniment), usually so that he may smoke a cigarette or rest his voice, and then continues on in sung poetry. Also at intervals of a half hour to one and a half hours, the poet stops entirely, enjoining the listeners to wish God's blessing on the Prophet again, and takes a full break-long enough to sip a glass of tea, smoke a cigarette, and let the audience discuss and evaluate the performance so far.

The transition back into the epic is accomplished in the same manner each time, though the prefatory sections will now be quite brief: praise to the Prophet, rhymed prose scene-setting, then the movement into the sung, epic voice. Throughout the evening, as guests come and go, as listencrs off er cigarettes, as the host offers refreshments, the poet also composes rhymed greetings and compliments to the audience members. Several other auxiliary genres of ten play a role in the sahra (see Chap. 4).

The sahra thus presented itsclf to me as an excellent context for study. It is the most common of the performance contexts actually taking place in al-Bakātūsh. It is also a context to which it was relatively easy for me as researcher to gain access. I could also, and did at times, host my own sahrāt to repay the generosity of friends, and, as host, I earned the right to determine which episode we were to hear. Finally, the relationships between the poet and his listeners in the sahra are intensified and made accessible to scrutiny by an outsider in the discussions and

29. Texts of this and other examples of madīh are given in Chapter 4. 
conversations that frame and fill the gaps in each performance. The poets' conceptualizations of the tradition, the listeners' conceptualizations, competing concepts of "authenticity," the boundaries of acceptable variation-all these were far more observable in the sahra than elsewhere. We must bear in mind, however, that this is but one of many different contexts for the performance of this tradition; the connoisseurship we encounter in our analyses of poet/audience interactions and other topics is, at least in present days, found almost exclusively within the frame of the sahra.

\section{Audiences of the Sahra}

Within the population of al-Bakātūsh, only a small percentage of people ever listen to performances of Sìrat Ban̄ Hilāl in any context other than the large public performances given at weddings and other celebrations. Though I recorded seventy-six sahrāt over the course of my I 986-87 fieldwork, in the presence of audiences that ranged from six to twenty listeners, these were attended primarily by the same core group of less than fifty listeners.

Even within the small group of people who do regularly listen to Sirat Bani Hilāl performances in private evening gatherings, a variety of attitudes can be found regarding the value of the epic and its importance or lack thereof. These attitudes tend to vary with two main factors: age and level of education. ${ }^{30}$ In many cases these two factors function in tandem and together define fairly distinct social groups within the village population. Until the I96os, reading and writing in al-Bakātūsh were taught primarily in the kuttāb, the traditional Qurānic schools in

30. The generalizations that follow are derived from an informal survey I conducted over several months which eventually included responses from nearly i 50 individuals. My aim was to determine basic attitudes concerning the epic and to determine roughly the frequency of Sìrat Banì Hiläl performances in al-Bakātūsh over the past few years. I posed a series of questions, usually within conversations; only with close friends did I ask the questions overtly as a survey. For this reason, many responses were incomplete, when conversations were interrupted or took different turns, when the setting was not appropriate for asking questions about education and personal background, and so forth. The basic format is as follows: What is your (I) name/age/occupation/education? (2) Did you listen to Sirat Bani Hilal before I arrived in the village? A lot? A little? (3) Which poets have you actually seen perform? (4) Has a poet perf ormed at any weddings or other occasions in your family recently? Which occasions? Who performed? (s) Have you ever seen poets performing elsewhere?

Positive responses were followed up with a series of secondary questions about the evaluation of poets, the importance, if any, of the epic, and personal reasons for listening to the epic. 
which the alphabet, memorization of portions of the Qur’ān, and some other basic religious texts are taught by religious shaykhs. ${ }^{31}$ Men who received their entire education in this system differ markedly in attitudes toward many aspects of village life from younger men who were educated in government schools. Only a handful of men over the age of sixty in al-Bakātūsh are literate, but these few share an essentially traditionalist viewpoint that was reinforced rather than contested by their education.

Men in al-Bakātūsh over sixty years of age are the strongest public supporters and patrons of the tradition, and several of the educated men of this generation are among the most active public patrons of the tradition. These men grew up in a society where the epic played a highly visible and respected role. In discussions with me, they approached the value and worth of the epic primarily as history, history they considered both ancient and veracious. They also lauded the heroes as models of manly virtue and honor, explained that the epic contains "big ideas" (afkär kabira), and contended that although the poets embellish and take liberties with the story in order to make the poetry entertaining, the epic is indeed the history of the Arabs.

Another primarily age-generated set of attitudes is found in the testimonies of men aged thirty to sixty or so. In this group, also largely illiterate though literacy is more common among men forty years old and younger, the epic is viewed with a certain amount of respect, but it is approached and patronized for the most part as entertainment. In conversation, educated men of this age group of ten at least initially derided the epic as it exists now as fabulous history with little connection to the events it describes. They often blamed the element of exaggeration and fantasy directly on recent generations of poets (including presentday poets). Several times I was told that if I had come fifty years ago, I would have heard the "real story" (al-qișa al-ḩaqiqiyya) of the Bani Hilāl. The sīra as it is told now, I was informed, is not "history" (tärikkh). The predominant opinion among literate men of this age group is that real history underlies the epic; but that the facts have had been warped into fantastic form by generations of poets, who added to and embellished the tales. The educated men of this age group rarely initiate performances of Sìrat Banì Hiläl, though they may regularly attend such gatherings. In contrast, less educated men of this group still occasionally host sahras and actively patronize the poets. Several men of this group

3I. For a detailed narrative account of this education system see Hussein, Egyptian Childhood (I982); also Sayyid Quțb, Tifl min al-qarya (A child from the village) (I945); see also the detailed descriptions given in Muhammad 'Abd al-Jawwād, Fì kuttāb al-qarya (In the village school) (1939). 
told me, however, that they did so as an act of charity toward the poets who are poor and needy (ghalbānin). A characteristic that these men cited several times in favor of listening to the epic was that it is "useful talk" (kalām mufid), that is, one benefits and is improved by the examples of the heroes who possessed "high morals and manners" (akhlāq) and were of noble character (asili). Active patronage of private evening gatherings for this age group seemed to vary more with factors of education than economic factors, though I do not have anything near a complete economic portrait of audience members.

Finally, I encountered only a handful of men under thirty who had ever attended a private performance of Sirat Banī Hiläl. A large number had never even heard a public performance, though an equal number had on one or more occasions heard at least a portion of a wedding performance. Almost all members of this age group in al-Bakātūsh have attended several years of government schooling. Many young men of this group attended performances out of curiosity during my stay in the village. Though some found it interesting, when I returned briefly in I988, none of these young men had attended further performances in the intervening eleven months. For most of these men, the epic evokes images of provinciality, illiteracy, and lack of sophistication.

Furthermore, those who favor contemporary revisionist and fundamentalist interpretations of Islam, almost all of whom are from this youngest age bracket, reject the epic as part of the matrix of folk or uneducated practices that they view as basically un-Islamic. These practices include the veneration of saints, the celebration of saints' festivals, the Sufi mystic brotherhoods, women's lamentations at funerals, the use of magic in any form, and other aspects of folk belief systems common in rural areas and in certain classes of urban society as well. Though outsiders may find little in the epic texts themselves which would seem objectionable (though saints and supernatural characters do appear in the stories), the epic is at present patronized almost entirely by those social groups against whom these young men have set themselves in opposition. In current social terms, the epic is strongly associated with traditionalist forces. The entire epic tradition is viewed by some groups as intrinsically bound up with the religious, social, and political views of its main body of appreciators.

These differing attitudes toward the epic are often discussed by poets in the privacy of their own homes. Cast in terms of advice to younger performers, their comments contain views such as the following: For old men, sing of the deaths of heroes; they like the sad parts, they like to hear shakwa [complaints sung about the vissicitudes of fate]. For the younger men sing light stories with lots of funny parts; entertain them. 
For the shabāb [young men in their late teens and twenties] sing love stories with beautiful women. ${ }^{32}$

The poets speak in particular of the younger men's lack of understanding and lack of patience with the serious parts of the epic. But this disinterest is not attributed to any lack of character among the young, nor do the poets of ten relate it to social changes; rather they simply remark that the epic is a taste one acquires with years. According to Shaykh Biyalī Abū Fahmī, "They are not yet 'up to the epic' " (mish calā qadd is-sīra). And Shaykh 'Abd al-Wahhāb Ghāzī tells us, "This type of talk is strange to them; their age is not yet up to its age" (ikkalām dā gharīb lahum; sinnihum mish calā sinnuh).

Later we examine in detail aspects of texts that have been manipulated by poets to fit their audiences. No example could be clearer though than the following brief descriptions of a young maiden, as sung by the same poet to three different groups. ${ }^{33}$ In the first instance the poet was singing to a mixed audience of men, women, and children. The maiden in question had a head as small and delicate as that of a dove, eyes like almonds, cheeks like roses, lips like cherries, and a neck as fine as that of a silver chalice $\left(\mathrm{ka}^{3} \mathrm{~s}\right)^{34}$ in the hand of a sultan.

The second time I heard this section I was in a group of young men: the description now began with the maiden's feet, which were as small as those of a dove, and then climbed to her legs which were like pillars of marble. Her thighs were smooth as silk and on them you could see the veins as in the finest Italian marble; these two pillars supported a lush garden in which there was a fountain, above which her belly pleated like a fold in a length of silk. In the midst was her navel, like a fine silver cup out of which a sultan might drink. This description was performed to whoops from the young men and cries for more. ${ }^{35}$

The final time I heard this description from the same poet, he was performing for a group of elderly men and I was the youngest person present. Gone were the romantic images and the eroticism; now all was sarcastic-her eyes struck him like two arrows, little did he know she would soon be striking him with her two slippers!

32. Paraphrased from views expressed many times by Shaykh 'Abd al-Wahhāb Ghāzĩ and Shaykh Tāhā Abū Zayd.

33. I paraphrase these versions because only one was recorded on tape, unlike the examples presented in detail in Chapters 4 and 5 . When I discussed with the poet all three descriptions, he readily acknowledged they were tailored to fit his listeners.

34. The standard word for "cup" in Egyptian Arabic is kubbayya, but I use the more poetic term "chalice" to communicate a similar feeling of archaism.

35. Even from this paraphrase the stability of certain elements can be perceived: we begin each time with something small which is likened to that of a dove, and we end with the image of the cup. 
The concept of differing audiences within the village context, then, reveals itself not only in the larger artistic choices but also in the finest of details. The poets speak not only of the difficulties they experience in playing to different audiences, but they recognize and discuss which members of their community are most talented at dealing with various age groups.

\section{Individual Performance Styles}

Varying audience attitudes toward the epic have helped differentiate the styles of the poets performing in the community of al-Bakātūsh; all of these styles, however, are part of the tradition. Although each poet has an individual repertory of devices for dramatizing or enlivening a performance (as I discuss in more detail in the ensuing chapters), each poet also leans toward a general style of performance and toward certain audiences with whom he is most comfortable. The following briefly describes the styles of four al-Bakātūsh poets as they perform in the sahra context:

Shaykh Biyalī Abū Fahmī is a showman par excellence. Heavyset, gregarious, sporting a black walrus mustache, and still in his fifties during my fieldwork (b. I93 I), he is the preferred poet of the young men $(\underline{s h} a b \bar{a} b)$ of the village. In performance he sways back and forth, waves his rabāb in the air, employs a wide repertory of facial gestures and humorous voices for such characters as old women, religious judges, Christians/Jews, and villains; the punch lines of his jokes are accompanied by a loud snap of the bow on the neck of the rabāb, a shout, or a deepthroated, hearty laugh. He has a powerful voice, clear enunciation, and is capable of singing, unamplified, for a large crowd. Shaykh Biyalī's performance style is one of rapidly changing textures: volume, melodies, gestures, facial expressions, quick switches from poetry to rhymed prose (sajc) to unrhymed prose, all conspiring to form a lively, highly entertaining kaleidoscope. His rhymes are ragged, his verses vary widely in length; he of ten misses a rhyme two and three times in a row before catching it again in a new sequence. Transcribing his texts proves difficult: his many digressions and excursions into jokes with the audience and commentaries leave many verses unfinished, and therefore much is left unsaid. I find it a formidable task to portray here the frenetic activity of these performances. He performs the complete Sirat Banī Hilāl repertory as it is known in al-Bakātūsh, but his renditions of ten lack the detail found in the older poets' versions. When he first recorded the sīra for me, it ran thirty-seven hours, with two episodes from his repertory not 


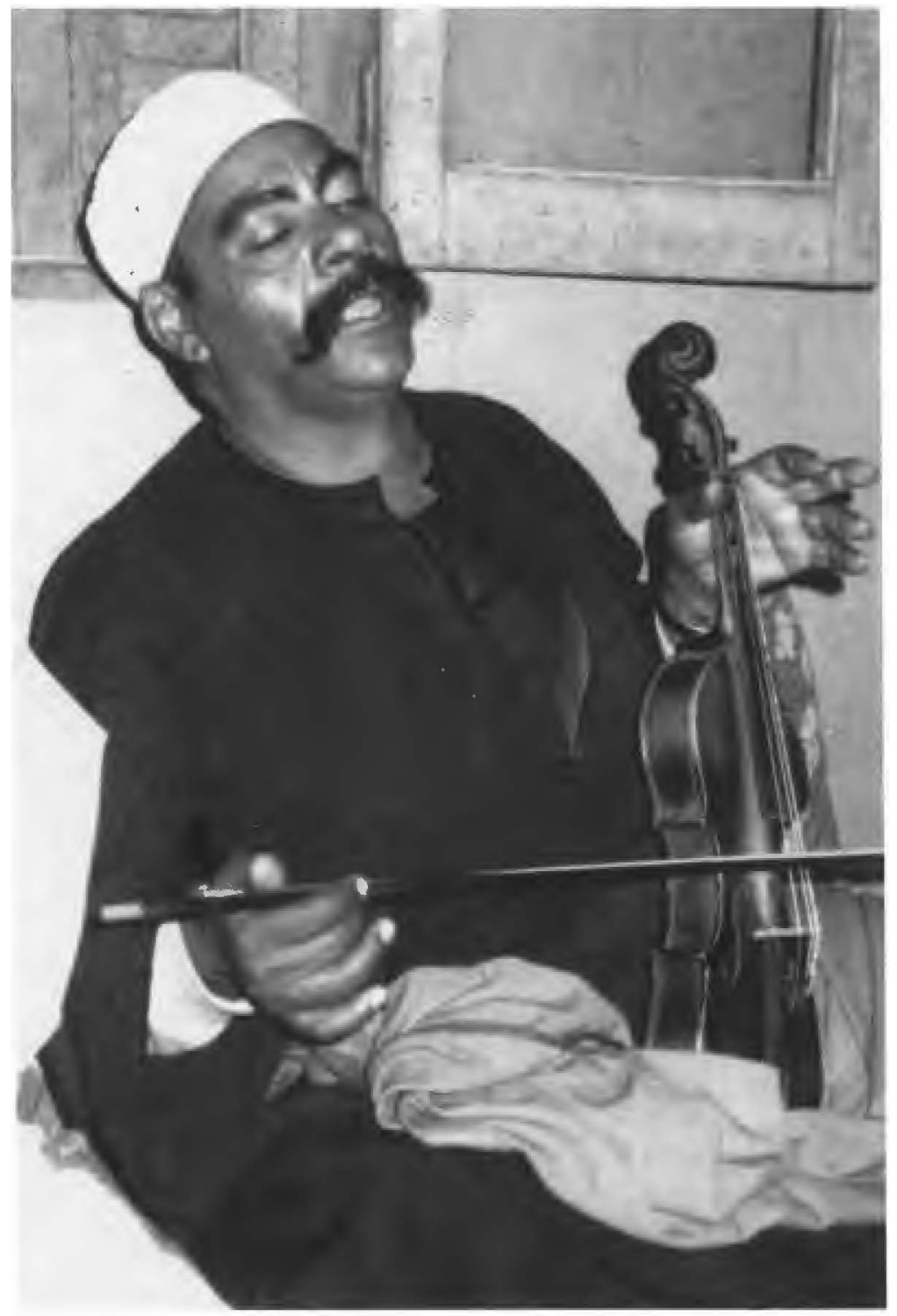

Shaykh Biyalī Abū Fahmī (shown performing on Western violin) 
recorded. When I heard him in unrecorded gatherings, several of his episodes nearly doubled in length.

Shaykh 'Abd al-Wahhāb Ghāzī is considered the doyen of the alBakātūsh poets. Small, thin, frail-looking but spry, he was nearly seventy (b. I9I9) when I recorded his repertory. Though he walks with a cane, his energy belies his years. He is lively in performance and also uses comic effects, though perhaps less of ten than Shaykh Biyali. He is the preferred poet of the older men of the village, among whom he has a staunch and loyal following. His stage presence bespeaks more dignity than a "showman" partially owing to his age and partially to his great store of knowledge about the history and genealogy of the village. During pauses in performances for tea and cigarettes, he entertains as much as while he is singing the epic; one way or another the audience is rarely disappointed. His repertory of facial expressions is more comic though perhaps more limited than Shaykh Biyalì's, and he is famous for his "shout" (shakhta) which he utilizes several times in a given performance, an effect anticipated by his listeners, something like the "surprise" in Haydn's Surprise Symphony. Two major problems, however, affect Shaykh 'Abd al-Wahhāb's performance style: the loss of many teeth has resulted in of ten unclear pronunciation, and with age his voice has lost much of its power-it is of ten difficult to hear him over the sound of the rabāb. As a result he can now only effectively perform in small groups, and these are of ten made up of people who have been listening to him and his renditions of the epic for years and even decades. When recording his performance I was able to ameliorate this condition by placing a microphone directly in front of him aimed to capture his voice rather than the rabāb. His poetry and rhymes are more regularly structured than Shaykh Biyalì's. I recorded only about two-thirds of his repertory from the sira (fifty-six hours); however, I also played with him in "lessons" (where we both played while he sang) for many additional hours and thus know his repertory better than that of most of the other poets except Shaykh Țāhā Abū Zayd. I never observed him in an unrecorded performance situation, however.

Shaykh Tāhā Abū Zayd, previous to my arrival, had not played in al-Bakātūsh itself for many years, preferring to play only on his extensive patronage circuit and at invited performances; he therefore had no following to speak of within the village. He is well over seventy (his date of birth is uncertain) but has a strong, sweet voice; his rabāb playing is considerably more controlled and coordinated with his singing than either of the poets described earlier. When, at my request, Shaykh Țāhā performed in a series of sahras, he surprised all present. His rhymes fell into place like clockwork, and his vocabulary was poetic, with more 


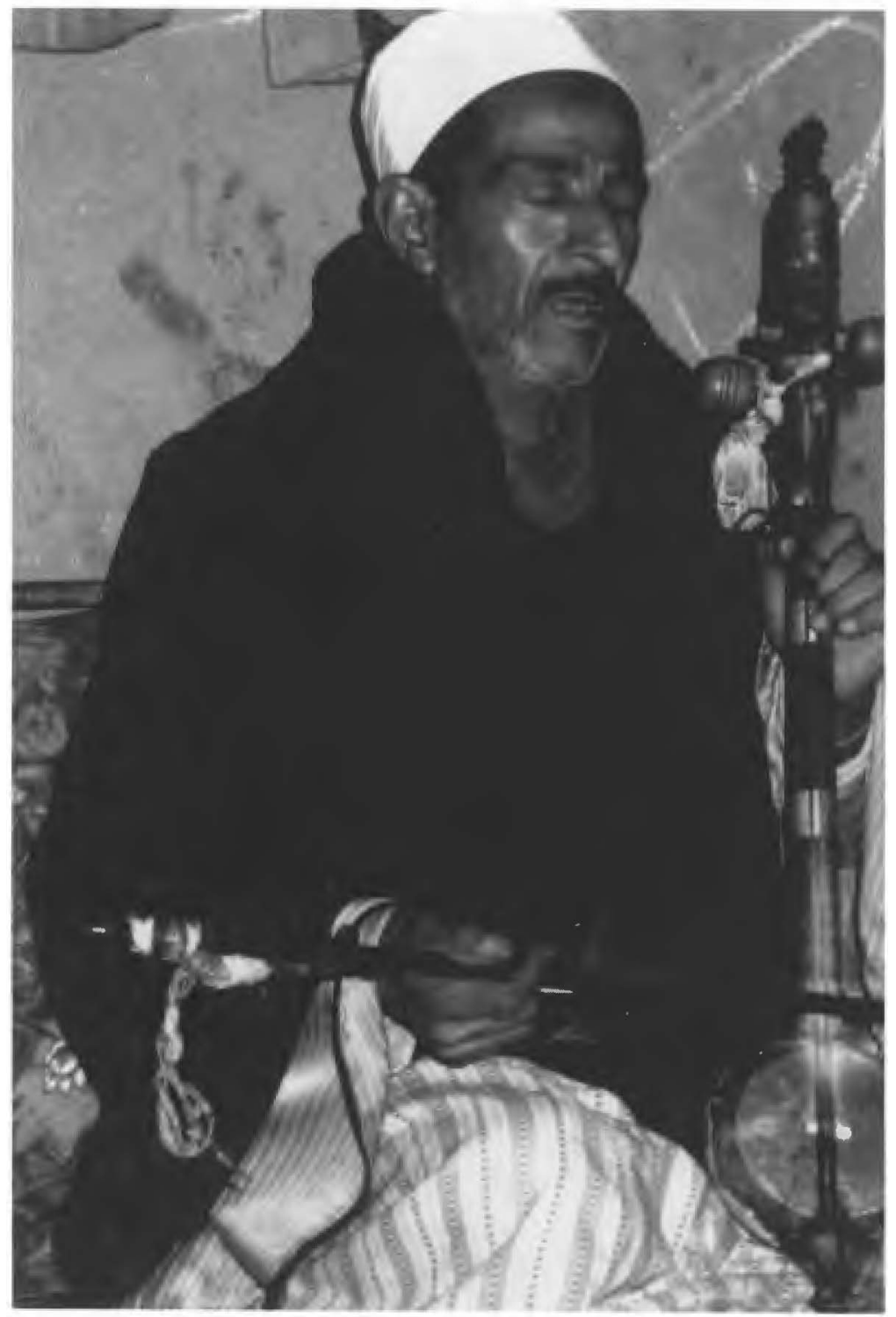

Shaykh 'Abd al-Wahhāb Ghāzī 


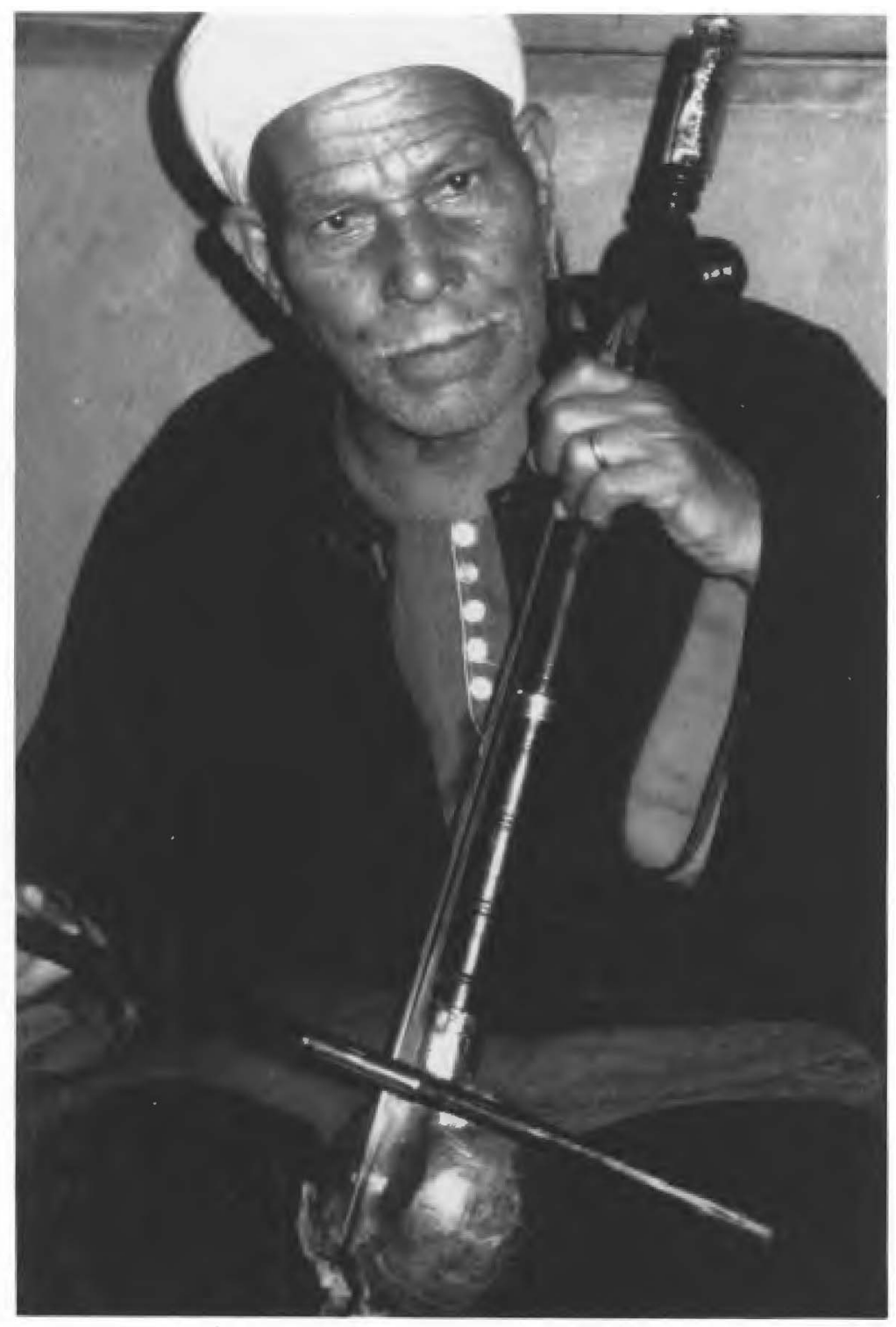

Shaykh Tāhā Abū Zayd 
"borrowings" from standard Arabic than the other poets use. His performance style is stark and even severe, for he employs virtually no facial expression, no gestures, no voice changes, and even eschews rapid melodic changes. He prefers not to "clutter" his performances with the other smaller genres usually used to fill out an evening: he never added a mawwāl, hitat baladī, or more than a couple of lines of praise poetry to Muhammad except at the direct request of an audience member. His performance style might be termed monotonous, but mesmerizing would certainly be a better characterization. I recorded what he described as his complete repertory from the epic (fifty-three hours), though he acknowledged that he could expand any of the episodes upon request. Once, in a discussion between Shaykh Tāāā, his son-in-law, and myself about adding detail or summarizing, he stated, "I can kill off the seven kings of the "Uqayla tribe in thirty minutes or I can take three hours doing it!" (6/22/87). Some listeners were very impressed with Shaykh TTâhă's renditions; others found his performance style too unchanging in delivery. My two college-educated assistants who helped with the transcribing of tapes both preferred Shaykh Țāhā's texts to those of all other poets. $^{36}$

Shaykh 'Abd al-Hamid Tawfiq is the youngest of these four poets (b. I935); he has a fine voice and is a good rabāb player. He uses little facial expression, no body movement, and little variation in tone, volume, or tempo. The result in this case, however, is monotonous, for he is generally unable to create any interactive relationship with his audience: his performances are completely devoid of jokes or commentary; when disturbances occur, he plods on with his singing, rather than incorporate the disturbance with a comment as other poets are wont to do. His repertory is limited: he knows only three episodes from the epic (Handal al-'Uqaylī, the Daughters of the Ashrāf, and Manșūr al-Habashī), which together total just under ten hours of performance. This repertory is virtually memorized; recordings from 1983 and 1987 show less variation than similar recordings from the older poets completed only a few minutes or days apart.

Of the fourteen poets who were living in al-Bakātūsh in 1983, five can be ranked as having full command of the entire epic as it is known in local repertory. Seven have much smaller personal repertories ranging

36. Shaykh Țanā's unusual phraseology and style can probably be traced to the fact that he is, both in clan affiliation and geographical origin, distinct from the other poets. His is the only family to have come to al-Bakātūsh, albeit nearly one hundred years ago, from the eastern province of al-Sharqiyya. The others came either from the south or west. 


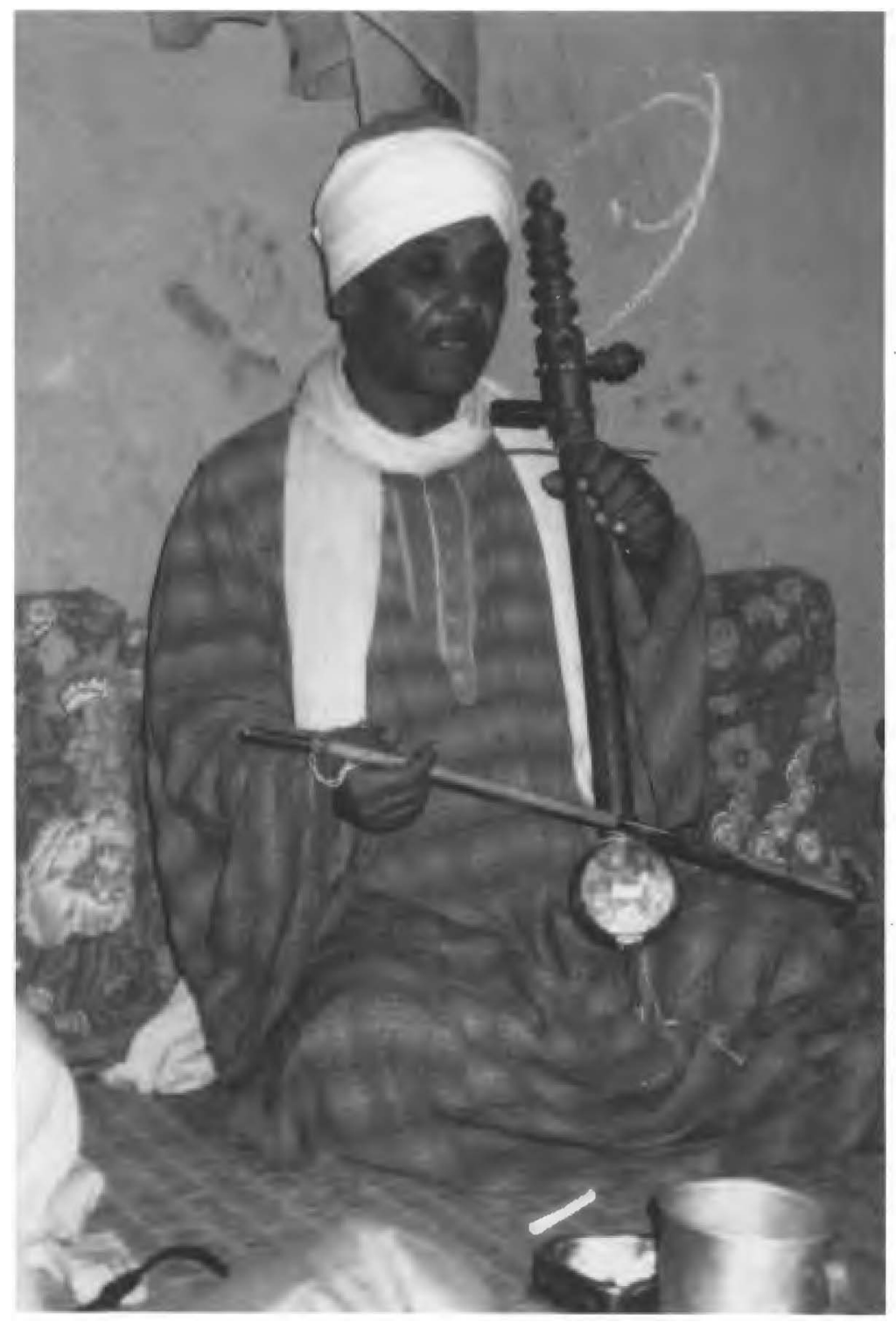

Shaykh 'Abd al-Hamīd Tawfìq 
from eight down to two episodes. Three of these lesser poets whom I had the opportunity of working with have died since I began my work in I983. In addition, Shaykh TTāhā Abū Zayd, my primary teacher and colleague in this research, suffered a stroke in 1988 and then died just before I completed this work. He was an extraordinary human being and a gifted poet. His modesty, despite his truly prodigious poetic abilities, is perhaps best summed up in my last conversation with him before leaving al-Bakātūsh after my 1986-87 fieldwork. Shaykh Tāha remonstrated me for paying so much attention to the poets of al-Bakātūsh rather than just the poems and asked that I not make "a big deal" of them in my book in America. There were far better poets a generation ago, and no one from his generation could compare to them, he said. I countered that the poetry they sang had been around for centuries and was rapidly disappearing, and that it is beautiful poetry of "big ideas." Besides, I told him, there is not a single poet in America who can sing even a few hours of poetry, let alone night after night for a month or more! "Not one?" he asked. "Not one." "Okay, well then go ahead and write what you have to write and God grant you success" (tabb iktib baqa illī candak w-allāh yinajjahak). I have been unable to bring myself to rewrite into the past tense the passages in this work which concern Shaykh Țāhā Abū Zayd.

There exists among the poets of al-Bakatūsh, and has probably always existed, a spectrum of differing abilities and of plain versus dramatic performance styles which includes a wealth of individual techniques such as the use of different voices for characters within the narrative, use of key melodies to mark joyful, tragic, or suspenseful scenes, facial expressions, hand and arm gestures, sudden shifts in volume, use of different "modes" of speech (prose, rhymed prose, and verse), and so on. Several researchers have been tempted to postulate that the plain, unadorned performance style is the oldest and most authentic manner of Arabic oral epic-singing and that the embellishing dramatic effects are modern accruals and basically compensatory techniques used by epic singers who cannot achieve high levels of eloquence.

Though this hypothesis initially sounds tenable, Lane, one of the earliest Western documenters of this performance tradition, clearly speaks of an animated performance style when he records that audiences are all "highly amused, not only with the story, but also with the lively and dramatic manner of the narrator." 37 This description is from the 1830 . Another early description, from Țāhā Huṣayn's autobiography referring to the I89os, seems to evoke just the opposite style. Here the poet 
performs calmly and staidly, though the listeners (as today in al-Bakātūsh) clearly have their own opinions to express: "the poet would begin to recite in a wonderfully sweet tone the doings of Abu Zaid, Khalifa and Diab, and his hearers would remain silent except when ecstay enlivened them or desire startled them. Then they would demand a repetition and argue and dispute. And so the poet would be silent until they ceased their clamour after a period which might short or long. Then he would continue his sweet recitation in a monotone." 38

These accounts and other evidence of pre-twentieth century performances do not clearly indicate that either one of the two ends of the spectrum are older or more authentic. A spectrum of styles has existed for at least the past I 50 years and probably much, much longer.

In this chapter I have linked traditional contexts, patronage structures, typical audience composition and attitudes, and individual poets' styles into some semblance of a larger interacting whole-a performance tradition. The challenge in analyzing specific performance texts now lies not merely in assimilating and including these domains as raw information, but also in delineating the balance and the relationships which concatenate among these various factors, neither shunting them aside as mere background description nor leaving them undifferentiated and univalent in their relationship to specific processes in actual performances.

38. Hussein, Egyptian Childhood, 2 (emphasis added). 